several workers, that there are apparently no penetrating particles incident as primaries on the top of the atmosphere; on the new theory they would, of course, have disintegrated in space before reaching the earth. Recently, Heisenberg and Euler" have shown how the spontaneous decay of the new particle can explain the striking, but hitherto inexplicable, failure of the mass absorption law for the penetrating rays in air and in dense materials.

By observations at ground-level and in the 'tube' station at Holborn, Follett and Crawshaw found that the intensity of the rays under a large thickness of air was about one half that found under the same mass of clay. Ehrmert' found a similar discrepancy between the absorption by air and by water. The effect was studied in considerable detail by Auger $^{7}$ and his co-workers, who obtained results which can be interpreted as showing the greater absorption of air at low pressure compared with air at normal pressure.

Heisenberg and Euler show how such observations can be explained quantitatively by the spontaneous decay of the new particle. This follows from the fact that in air the distance travelled by the particle during its mean time of life is rather less than its range as defined by its ionization loss, whereas in dense materials the latter range is very much the smaller. Thus in air the decay increases the apparent absorption, while in dense materials it has little or no effect.

A simplified form of the calculations of Heisenberg and Euler shows clearly how the order of magnitude of the time of decay can be obtained from the observations. For example, from the measurements of Follett, or of Ehrmert, it can be seen that the intensity under $60 \mathrm{~m}$. water- equivalent of air is about a half that under the equivalent thickness of clay or water. We conclude, therefore, that one half the rays decay spontaneously in the time required to traverse $60 \mathrm{~m}$. water-equivalent of air, that is, a distance of about $60,000 \mathrm{~m}$. The mean time of life $T$ is therefore of the order of $6 \times 10^{8} / 3 \times 10^{10}=2 \times 10^{-4}$ sec. Since the value of $\gamma$ for the rays, assuming a mean energy of $10^{10} \mathrm{e}$. volts and a mass of $200 \mathrm{~m}_{0}$, is about 100 , we get $T_{0}=2 \times 10^{-6}$ sec. Though this value is about four times that predicted by Yukawa, the agreement must be considered as most satisfactory in view of the early stage of the theory and of the crudeness of the deductions from the experiments.

There seems, therefore, to exist definite experimental evidence for the spontaneous decay of the new particle. The accurate determination of this time of decay and of the mass of the particle is now one of the outstanding problems of cosmic ray research. It is possible, of course, that there are other methods than that of spontaneous decay by which the new particles may disappear, but further experimental results are needed before any certainty can be attained on this point. Since there can be no particles of this type incident on the atmosphere, they must all be produced in the atmosphere as secondaries to the incident electrons. No evidence as to how this occurs has yet been found.

\footnotetext{
${ }^{1}$ Neddermeyer and Anderson, Phys. Rev., 51, 884 (1937).

Y Yukawa, Proc. Phys. Math. Soc.Japan, 19, 1084 (1935); Yukawa and Taketani, M., ibid., 20 (1938).

s Bhabha, Nature, 141, 117 (1938).

- Heisenberg and Euler, in the Press. (I am greatly indebted to Prof. Heisenberg and Dr. Euler for communicating these new results to me.)

Follett and Crawshaw, Proc. Roy. Soc., A, 155, 546 (1936).

6 Ehrmert, Z. Phy8., 106, 751 (1937).

'Auger, Ehrenfest, Fréon and Fournier, C.R. 204, 257 (1937).
}

\title{
The Old Stone Age in European Russia*
}

\begin{abstract}
A RCHFOLOGISTS are generally agreed as to the importance of obtaining more precise and detailed information about the actual conditions of the cultural stages of eastern Europe, of which the greatest part is European Russia. At the same time, the total of information relating to the palæolithic period in that region, which has appeared in English, French and German, is negligible; and knowledge of the period is far from satisfactory. Dr. Golomshtok, accordingly, at the suggestion of Mr. H. H. F. Jayne, director of the University Museum of Pennsylvania, with " "The Old Stone Age in European Russia". By Eugene A. Golomshtok. Trans. Amer. Phil. Soc., N.S., 29, 2, March 1938. Pp. $v+191-468+x x x$ ii plates.
\end{abstract}

the assistance of the Board of Managers of the Museum, and a grant from the National Research Council, has brought together all the data available, regardless of the language of publication, but so far as possible endeavouring to present the firsthand evidence of the excavator. Some idea of the importance and magnitude of his undertaking will be gathered from the fact that while Burkitt lists nine sites, MacCurdy fourteen, and Ebert and Menghin six and seven respectively, the present survey, which, it is pointed out, is not to be regarded as final, covers no fewer than 105 sites, to which must be added eight sites on which human remains have been found, without artefacts, but 
in association with a fossil fauna, or otherwise dated.

In the history of palæolithic studies in Russia up to 1917, the first site discovered was Gontzi in the Poltava region, where fossil bones in association with a flint implement attracted the attention of Kaminsky, a local teacher, in 1874. Three years later, Count U. S. Uvarov, the father of Russian prehistoric archæology, established the existence of a palæolithic site on his estates near the village of Karacharovo; and in $\mathbf{1 8 7 9}$ his collaborator, Poliakov, discovered Kostenki I, one of the most important sites in Russia. The visit of K. S. Merezkovski, a botanist, to the Crimea resulted in the discovery of a number of cave sites, Suren I, Cherkess-Kermen, etc. ; while from 1880 onward palæolithic cultures were determined in the Dnieper region (Antonovitch), Nova-Alexandria (Kristaphovitch), Tomsk (Kaschenko), Cyrill St., Kiev (Khvoiko), and Ilskaya in the Caucasus (Baron de Baye). Uvarov and Volkov, by their summaries of existing knowledge, and the latter also by training young archæologists in his excavations at Mezine (1908), placed palæolithic researches in Russia on a truly scientific basis. Among Volkov's pupils, P. P. Ephimenko is the most distinguished archæologist in Russia of to-day.

Under the Soviets, archæological studies have received a tremendous impetus, and the interest of the general public has been much enhanced. Old sites have been re-examined and new sites opened. In 1922, Zamiatnin discovered and examined Borshevo, near Kostenki, where also he excavated new sites. Important investigations have been carried out by G. A. Bonch-Osmolovsky among others in the Crimea. In Siberia, extensive studies have been made in the Yenisei district and in the region of Irkutsk; while archæology has been supplemented by a more detailed study of quaternary geology and palæontology by Pavlov, Gromov and others. The only survey of this work hitherto in a language other than Russian is by L. Sawicki ; but it is in Polish.

The materialistic interpretation of history now followed under the Soviets requiring the investigation of every factor that influenced culture, expeditions have studied, alongside the archæological and ethnological data, local geology, fauna, flora and climate. Microscopic examination of charcoals have afforded much information as to flora and climatic conditions.

Russian students of the development of culture, being firm believers in the evolutionary materialistic explanation of cultural changes, are strongly opposed to the theories of cultural borrowings and migrations of Western archæologists, as well as to the antiquarian attitude of interest in antiquities per se, which forgets the people who made them.
Again, Russian archæologists claim that their statistical and functional methods of study have, on one side, saved them from laying undue stress on 'leading' types, which give a distorted view of the culture, and on the other they have been led to such discoveries as those of underground dwellings of palæolithic man, which have been overlooked in the West.

Before turning to archæological discovery, the conclusions of recent geological and palæontological investigations may be summarized as follows: The existence of three, and only three, definitely traceable glaciations has been established. These are Mindel, Riss and Würm. The Gunz was very weak and either its traces were obliterated by subsequent advances of the ice, or it was not effective. The other three glaciations appear to correspond in time and in general characteristics with those of western Europe. The fauna which accompanied the various climatic changes generally corresponds to that of western Europe, but on the whole has a colder character. The extremely warm species are few and not abundant. The Crimea and Caucasus show local variation.

The discovery which has probably attracted most attention among Western archæologists in the post-War years is that of the human skeletal remains, generally known as the Podkumok skull, from the Caucasus. These remains were found in the autumn of 1918 in the course of excavations for a sewer in the town of Piatigorsk. They were below a pottery vessel and a polished stone perforated disk; but owing to political conditions, no observations of the exact position of the human remains was possible. Later the remains were dated on the basis of general geological conditions resulting from a survey by P. V. Rengarten. According to this, the find was in the fifteen-metre terrace of boulder clay deposits on the left bank of the Podkumok River. General conditions for the North Caucasus show three terraces at $15 \mathrm{~m} ., 60 \mathrm{~m}$. and $120 \mathrm{~m}$. respectively, all belonging to the Quaternary Age. On this showing the Podkumok find belongs definitely to the Würm glaciation.

The Podkumok remains are part of a cranium consisting of almost the whole of the frontal bone, the front parts of both temporal bones and a small part of the nasal bone, a fragment of the right side of the lower jaw with five teeth, and some other fragments of the skull and skeleton. The bones are thin and small and the muscular attachments weak. Gremiatsky identifies the remains as those of a female of from fifty-five to sixty years of age of the Neanderthal group, but showing an approach to $H$. sapiens, which would place it between Neanderthal and 'modern man'.

While Gremiatsky holds that this find definitely establishes the existence of Neanderthal man in 
the Caucasus in conditions very similar to those of the diluvial period of western Europe, there has been a disposition recently in Russia to question the Neanderthal affinities of Podkumok, while Sir Arthur Keith, it is noted, has expressed the opinion that it is altogether of the neanthropic species.

In this connexion, it is to be remarked that the biological conception of the development of man favoured by Soviet archæologists pictures that development as one uninterrupted chain of evolution, and the view of Western archæology, that the Neanderthal race died out and was replaced by a new Cro-Magnon race, is vigorously denied. Cro-Magnon is considered to be a direct descendant of Neanderthal man; and it is held to be even possible that this transformation may have taken place in Europe.

A number of human cranial fragments have been found with fossil bones of an extinct fauna at several sites on the Lower Volga. Of these the most considerable are known as Undora I and Undora II, from the island of that name, on which they were found. The skulls have been reconstructed by A. P. Pavlov, and classified by him as belonging to a group which includes Galley Hill, Brünn and Canstatt, of early post-glacial date.

The dating and interpretation of cultural finds by Soviet prehistorians are often founded on certain basic assertions, which lead to important divergences from the views held by Western archrologists. The acceptance of the universal evolutionary scheme of cultural development, with the material basis as the main determinant, results in a fairly well outlined succession of the phases of social structure, corresponding to the different stages of industrial development. The centre of gravity lies in the method of production, and strenuous objection is taken to 'migrations', 'borrowing' and 'superior races'. This view, however, leads to certain difficulties and inconsistencies. Ephimenko, for example, when faced by certain very primitive characters in Neanderthal man, attributes them to the degeneration which arose from close interbreeding in the small Neanderthal group. Yet on the other hand, the relatively poor industry of the Mousterian group is taken as a proof of the tenacity and ingenuity of Neanderthal man.

To account for the superior physical characters and industry of Cro-Magnon man, it is argued that new conditions of existence changed the character of the social structure, creating, in place of the closed primitive horde, more complex groups of intercommunicating hordes. Hence arose rapid cultural growth and the formation of a new physical type, which entered the history of Europe during the Upper Palæolithic period as the CroMagnon race. This view, it is only fair to say, is not accepted by all Soviet archæologists. BonchOsmolorsky maintains that while Neanderthal man differed physically from modern man, these differences were such as to limit his functional possibilities. Thus the structure of his hands prevented him from making long knife-like blades, which required a very accurate blow for their detachment. Hence Neanderthal man and CroMagnon man represent stages in the process of perfection, which are the result of physical changes dictated by the gradual development of social life.

On summarizing the material from the one hundred and thirteen localities listed, certain generalizations are seen to emerge. European Russia would appear to be very poor in remains of Lower and Middle Palæolithic cultures. No true Chellean and Acheulean sites are found. Two accidental finds of coups-de-poing are doubtful ; but a series of Acheulean sites reported in the Caucasus by Zamiatnin may change these conclusions, when data are available. The so-called 'pre-Mousterian' cultures, such as are found in the lower layer of La Micoque and La Ferrassie, are represented by the lower layer of Kiik Koba. The dating of this site, however, is far from settled. The upper layer is regarded as pre-Mousterian or archaic Mousterian. Transitional between Middle and Upper Palæolithic, corresponding to Abri Audi, is Shaitan Koba. These sites are dated by Gromov as from Riss-Würm to the maximum of Würm.

In the Upper Palæolithic, there is an absence of stratigraphical evidence of distinctly different cultural layers. In the cave sites of the Crimea and the Caucasus, where geological evidence is lacking, it is frequently necessary to rely on analysis of the faunal complex. The bulk of Upper Palæolithic sites are open camp sites of hunting peoples. In these, two cultural complexes can be distinguished. The first of these complexes consists of large accumulations of animal bones, very much like the well-known bone piles from Předmost, Moravia. As a rule they contain very few stone implements. The second complex, according to most Russian archæologists, represents the place of more or less permanent habitation of these hunting groups. It is characterized by red pigmentation of the ground, due to the presence of ochre, the remains of open fires, filled with ashes and charred bones, and usually by large quantities of stone and bone tools. In several cases, definite traces of permanent habitations were found, sometimes with stone slab foundations, well preserved fireplaces, copings, niches in which objects were kept, and caches of flint and bone tools. Nearby were storage pits and primitive 'ovens'.

The flint industry of the Russian Upper Palæolithic presents almost every variety of form known 
to western Europe, except the very specialized classical 'Solutrean'. The 'leading' bone forms, such as the Aurignacian cleft base and harpoons, are totally absent. Consequently an entirely new set of criteria for dating is necessitated; and the subdivisions of Upper Palæolithic industries are employed with different implications. Aurignacian, Proto-Solutrean, Solutrean and Magdalenian are used to designate stages in the development of culture, rather than specific cultures. Thus bifacial flaking and the point $\grave{a}$ cran, even in its most atypical form, are taken as indicating Solutrean temporal affinities. Taking this as the middle point, industries where these characteristics are less prominent are taken as older, that is, as Aurignacian; others which show a general decadence of technique are said to be younger, that is, Magdalenian. Hence Ephimenko finds true Aurignacian in one site only, Suren I. The rest of the Upper Palæolithic sites, excluding the transitional with microlithic industries, he classifies as Aurignacian-Solutrean and Solutrean-Magdalenian, affirming that no true Solutrean sites are known in Russia.

Basically, we seem to have in European Russia the Early, Middle and Late Upper Palæolithic industries, all characterized by the blade technique, which starts very much like the Aurignacian in western Europe, develops, acquires some peculiar traits, suggesting Solutrean influence, and then slowly degenerates, finally reaching the stages of a microlithic industry.

\section{Hugh Miller, I802-56}

\section{Commemoration at Cromarty}

$\mathrm{T}$ HE rise of geological knowledge in the first half of last century was marked by the appearance of innumerable books dealing with the rich mass of observations which could be made by even superficially interested persons. Most of these books are wisely forgotten; but in the residue there are some of the strongest foundations of the present science. One stands out among the greatest, both in content and in its influence on others: "The Old Red Sandstone, or New Walks in an Old Field", by a man who was proud to be a journeyman mason. Buckland said that "geologists were amazed and delighted" by this book, and his phrase must be echoed to-day, almost a century later.

Hugh Miller wrote other books, many of them dealing with geological topies, but "The Old Red Sandstone" seized popular imagination and made this perhaps the most widely known geological formation. He had a few comments on the geology of his native Cromarty in "Scenes and Legends of the North of Scotland", which was appreciated by distinguished critics for its literary qualities. "The Old Red Sandstone" was published serially in 1840 in the Witness newspaper, of which Miller was editor ; it appeared as a book in 1841 . "Footprints of the Creator, or the Asterolepis of Stromness", followed in 1847 as a reply to the "Vestiges of Creation", in which Chambers had published anonymously an evolutionary theory. Miller's answer was, in its time, a remarkable and able contribution to Christian apologetics. He dealt further with the hotly debated frontier-territories of science and religion, in "The Testimony of the Rocks" (1857), which received its final corrections on the day of its author's death; and in the same year was published "Voices from the Rocks ; or Proofs of the Existence of Man during the Lower Palæozoic Period", which is now best forgotten. Posthumously, in 1858, Symonds edited the manuscript of "The Cruise of the Betsey ... ; with Rambles of a Geologist", which, in my opinion, contains the most delightful prose of all Miller's output. Other less important geological books and papers, besides other works, came from his pen.

To Hugh Miller geology was an incident in the revelation of religion, but he was usually a shrewd and accurate observer who faced the deductions which he could make from the facts of his observations. In the dedication to "Footprints of the Creator" he wrote: "The ingenious and popular author [Chambers] whose views on Creation I attempt controverting, virtually carries his appeal from science to the want of it. I would fain adopt an opposite course." He was a strong believer in the notion of successive creations, and the great profusion of fossil fishes in the nodule-beds which occur at certain levels in the Middle Old Red Sandstone of the Moray Firth led him to describe these horizons as "platforms of death". For some time his efforts were directed to reconciling Biblical and geological knowledge, and in the atmosphere of nearly a century later it is not always easy to estimate the influence of these attempts.

His indignation was powerfully aroused by two 